clined to speculate that these males did not find a mate here and also to wonder whether they might have nested if they had found a mate.

\title{
THE AUTHENTIC SPARROW HOUSE?
}

\author{
by VIRGINIA BARTKOW*
}

"The woodpecker pecked out a little round hole

And made him a house in the telephone pole."

So went the nursery rhyme by Elizabeth Madox Roberts, but that is not how it happened in our garden.

Several years ago I asked Michael to build me a bird house. He did, but being a perfectionist, had to make it authentic - an authentic sparrow house. For two years it was empty; no authentic sparrows showed up, and all the other birds ignored it. And then we moved to Langford.

Almost immediately it was occupied by sparrows. However, their tenancy was challenged by starlings, so Michael had to put a new front with a smaller hole, over the opening. The second year, swallows tried to drive the sparrows out but were unsuccessful, and nested instead in a small Tupperware birdhouse at which, Michael said scornfully, no selfrespecting bird of any kind would even look. He had barely hung it up before the swallows were in.

The next year, so there would be plenty of nests for everyone, and stimulated by the bluebird nesting competition, Michael built several new houses, single ones, double ones, round, square and octagonal. We had

*Reprinted from Victoria Naturalist, Jan., 1974. them all up in plenty of time, but the year was late all down the line... The sparrows and swallows fought intermittently over the sparrow house, until finally the swallows got down to business and raised one family in it.

The only birds that were completely organized were the nuthatches. They have a nest in a red alder - a tiny slit in the trunk, so narrow that even when the bird vanishes you don't believe it. Every year they raise three families in this nest, but last year there was extra activity. One busy little female filled every bird house in the garden, except the sparrow house, with twigs, stuffing the holes so that nothing but a nuthatch or a chickadee could possibly get into them, and after every twig was laboriously jimmied into position, she would carol out a paean of accomplishment.

Now it is late November, and every house is busy with birds. Somehow they have managed to move the nuthatch twigs, and apparently are evaluating the nesting possibilities sitting inside, peering out the doors, chirping to their mates. All but the sparrow house, and that has been appropriated by a Hairy Woodpecker! Happy "Hairy" pounded away until the hole was bigger than the original opening, squeezed inside,

"And as I watched, he poked out his head,

Black and white and topped with red." 
